\title{
Supplementary Information for: Glacial sedimentation, fluxes and erosion rates associated with ice retreat in Petermann Fjord and Nares Strait, NW Greenland
}

Kelly A. Hogan ${ }^{1,2}$, Martin Jakobsson ${ }^{3,4}$, Larry Mayer ${ }^{2}$, Brendan Reilly ${ }^{5}$, Anne Jennings ${ }^{6}$, Alan Mix ${ }^{5}$, Tove 5 Nielsen $^{7}$, Katrine J. Andresen ${ }^{8}$, Egon Nørmark ${ }^{8}$, Katrien Heirman ${ }^{7,10}$, Elina Kamla ${ }^{7,9}$, Kevin Jerram ${ }^{2}$, Christian Stranne 3,4

${ }^{1}$ British Antarctic Survey, Natural Environment Research Council, High Cross, Madingley Road, Cambridge, CB3 0ET, UK

${ }^{2}$ Center for Coast and Ocean Mapping, University of New Hampshire, NH 03824, USA

${ }^{3}$ Department of Geological Sciences, Stockholm University, 10691 Stockholm, Sweden

$10 \quad{ }^{4}$ Bolin Centre for Climate Research, Stockholm University, Stockholm 106 91, Sweden

${ }^{5}$ College of Earth, Ocean, and Atmospheric Sciences, Oregon State University, Corvallis, OR 97331, USA

${ }^{6}$ Institute of Arctic and Alpine Research, University of Colorado, Boulder, CO 80309-0450, USA

${ }^{7}$ Geological Survey of Denmark and Greenland, Øster Voldgade 10, 1350 Copenhagen K, Denmark

${ }^{8}$ Department of Geoscience, Aarhus University, Hoegh-Guldbergs Gade 2, DK-8000, Aarhus C, Denmark

$15{ }^{9}$ TNO, Geological Survey of the Netherlands, Princetonlaan 6, NL-3584 CB Utrecht, The Netherlands

${ }^{10}$ Rambøll Management Consulting, Hannemanns Allé 53, DK-2300 Copenhagen S, Denmark

Correspondence to: Kelly A. Hogan (kelgan@bas.ac.uk)

\section{Seismo-acoustic facies / lithofacies correlation}

20 Seismo-acoustic facies identified from sub-bottom profiler (SBP) and seismic-reflection profiles were correlated with particular sediment units (lithofacies) as described from marine sediment cores also acquired during the Petermann 2015 Expedition or previously collected from the study area (Supp. Table 1). This was achieved by comparing SBP profiles at individual core sites with core CT-scans, core photographs and core descriptions. Seismo-acoustic facies I (bedrock), II (subglacial till) and VI (grounding-zone wedge units) were not recovered by either piston or gravity cores generally because

25 they were too deep in the stratigraphy to be sampled or were not able to be sampled by these types of coring devices (i.e. bedrock). Therefore, only seismo-acoustic facies III, IV and V were correlated with sediment lithofacies (Supp. Fig. 1); details of the correlations and a brief description of the core lithofacies is provided below.

Seismo-acoustic facies III (OD1507-41GC, HLY03-05GC): The upper part of core OD1507-41GC from Petermann Fjord (Supplementary Table 1) recovered a brown, homogeneous clay with dispersed sand and clasts (Supp. Fig. 1a). This lithofacies is correlated with seismo-acoustic facies III (Supp. Fig. 1e) and is consistent with distal glaciomarine sediments deposited largely from suspension with dispersed IRD (cf. Elverhøi et al., 1989; Powell \& Domack, 2002). Core HLY03-05GC (Supp. Fig. 1b) samples the same seismo-acoustic facies (Supp. Fig. 1f) but from Robeson Channel in the northern part of the study area just beyond the S4 ridge. The sedimentology of this core was described by Jennings et al. (2011) who identified bioturbated muds to $112 \mathrm{~cm}$, a transitional laminated pebbly mud unit from 112-125 cm and a laminated mud unit from 125 
$35 \mathrm{~cm}$ to the base of the core. The laminated units were interpreted as distal glaciomarine sediments with the transitional unit reflecting the break up of ice in Nares Strait and Kennedy Channel (Jennings et al. 2011).

Seismo-acoustic facies IV (OD1507-37PC): This core (Supp. Fig. 1c) penetrated seismo-acoustic facies IV in Petermann Fjord (Supp. Fig. 1g) in a basin around $2 \mathrm{~km}$ from the ice-tongue margin as it was in 2015. It sampled grey-brown clay with dispersed clasts interrupted by multiple coarse, sand units (typically $<10 \mathrm{~cm}$ thick) that are normally-graded and have sharp basal

40 contacts. The clay with clasts is interpreted as glaciomarine sediments with IRD and the individual sand units have properties consistent to gravity-flow deposits (GFDs) (i.e. erosive at their base and grading upwards; e,g, Bøe et al., 2004; Gilbert et al., 2002). Although such thin sand units may not be resolved on the sub-bottom profile over the core site, this lithofacies supports our interpretation of the seismo-acoustic facies as glaciomarine units with interbedded GFDs.

Seismo-acoustic facies V (OD1507-52PC): Core OD1507-52PC (Supp. Fig. 1d) was recovered from a stratigraphy that

45 included discrete lenticular bodies defined as seismo-acoustic facies V (Supp. Fig. 1h). The core sampled laminated muds interbedded with diamictic units with sharp contacts consistent with sediment flow deposits consisting of glacigenic debris (cf. Laberg \& Vorren, 2000). Note that the individual diamictic units in the core are not resolved on the SBP profile as discrete reflections.

\section{Drainage basins for glacial erosion rate calculations}

50 In order to estimate glacial erosion rates for the Petermann Ice Stream and other Greenland outlet glaciers for comparison the area of the glacier catchment or drainage basin area $\left(A_{d r}\right)$ is required (see Equation 1 in the main text). For subglacial erosion to occur the ice sheet must be moving over the bed, i.e. ice cannot be frozen to the bed and, therefore, we exclude areas where ice velocities are $<50 \mathrm{~m} \mathrm{a}^{-1}$. For Petermann and Jakobshavn glaciers, the erosion rates that we calculate are for a period during deglaciation. Thus, in the absence of ice-sheet velocities for a deglacial ice sheet (modelled or otherwise inferred), we utilise

55 ice-sheet velocities from the modern Greenland Ice Sheet (GrIS) to define the drainage basin areas for these catchments. Modern GrIS velocities for the Petermann, Jakobshavn and Kangerlussuaq glacier systems are from the MEaSUREs Greenland Ice Velocity: Selected Glacier Site Velocity Maps from Optical Images, Version 2 dataset for 2017-2018 (Howat, 2017). In both catchments we extend the drainage basin to include the part of the fjord up to the fjord-mouth sill but now not occupied by ice (Supplementary Fig. 2a, b). The northern and southern boundaries of the Jakobshavn drainage basin were digitised from

60 the Zwally et al. (2012) drainage system divides.

\section{References}

Bøe, R., Longva, O., Lepland, A., Blikra, L. H., Sønstegaard, E., Haflidason, H., Bryn, P., and Lien, R.: Postglacial mass movements and their causes in fjords and lakes in western Norway, Norsk Geologisk Tidsskrift, 84, 35-55, 2004. 
Elverhøi, A., Pfirman, S. L., Solheim, A., and Larssen, B. B.: Glaciomarine sedimentation in epicontinental seas exemplified by the northern Barents Sea, Marine Geology, 85, 225-250, 1989.

Gilbert, R., Nielsen, N., Möller, H., Desloges, J. R., and Rasch, M.: Glacimarine sedimentation in Kangerdluk (Disko Fjord), West Greenland, in response to a surging glacier, Marine Geology, 191, 1-18, 2002.

Howat, I. M.: MEaSUREs Greenland Ice Velocity: Selected Glacier Site Velocity Maps from Optical Images, Version 2, Howat, I. M. (Ed.), NASA National Snow and Ice Data Center Distributed Active Archive Center. Ice Velocity, Boulder, Colorado USA., 2017.

Jennings, A. E., Sheldon, C., Cronin, T. M., Francus, P., Stoner, J., and Andrews, J.: THE HOLOCENE HISTORY OF NARES STRAIT: Transition from Glacial Bay to Arctic-Atlantic Throughflow, Oceanography, 24, 26-41, 2011.

Laberg, J. S. and Vorren, T. O.: The Trænadjupet Slide, offshore Norway - morphology, evacuation and triggering mechanisms, Marine Geology, 171, 95-114, 2000.

75 Powell, R. and Domack, G. W.: 12 - Modern glaciomarine environments. In: Modern and Past Glacial Environments, Menzies, J. (Ed.), Butterworth-Heinemann, Oxford, 2002.

Zwally, J. H., Giovinetto, M.B., Beckley, M.A., and Saba, J.L.: Antarctic and Greenland Drainage Systems, GSFC Cryospheric Sciences Laboratory, at http://icesat4.gsfc.nasa.gov/cryo_data/ant_grn_drainage_systems.php, 2012. 


\begin{tabular}{|l|l|l|l|l|l|}
\hline Core name & Latitude $\left({ }^{\circ} \mathrm{N}\right)$ & Longitude $\left({ }^{\circ} \mathrm{W}\right)$ & Water depth $(\mathrm{m})$ & Length $(\mathrm{cm})$ & Cruise / reference \\
\hline OD1507-37PC & 80.96575 & 60.95450 & 1041 & 847.6 & $\begin{array}{l}\text { Petermann } \\
\text { Expedition }\end{array}$ \\
\hline OD1507-41GC & 81.19378 & 61.97715 & 991 & 440 & $\begin{array}{l}\text { Petermann } \\
\text { Expedition }\end{array}$ \\
\hline OD1507-52PC & 81.24183 & 63.99833 & 517 & 541 & $\begin{array}{l}\text { Petermann } \\
\text { Expedition }\end{array}$ \\
\hline HLY0301-05GC & 81.62143 & 63.25778 & 797 & 371 & $\begin{array}{l}\text { HLY0301 Jennings et al. } \\
\text { (2011) }\end{array}$ \\
\hline
\end{tabular}

Supplementary Table 1. Core locations and information for cores used in seismo-acoustic facies and lithofacies correlations. 


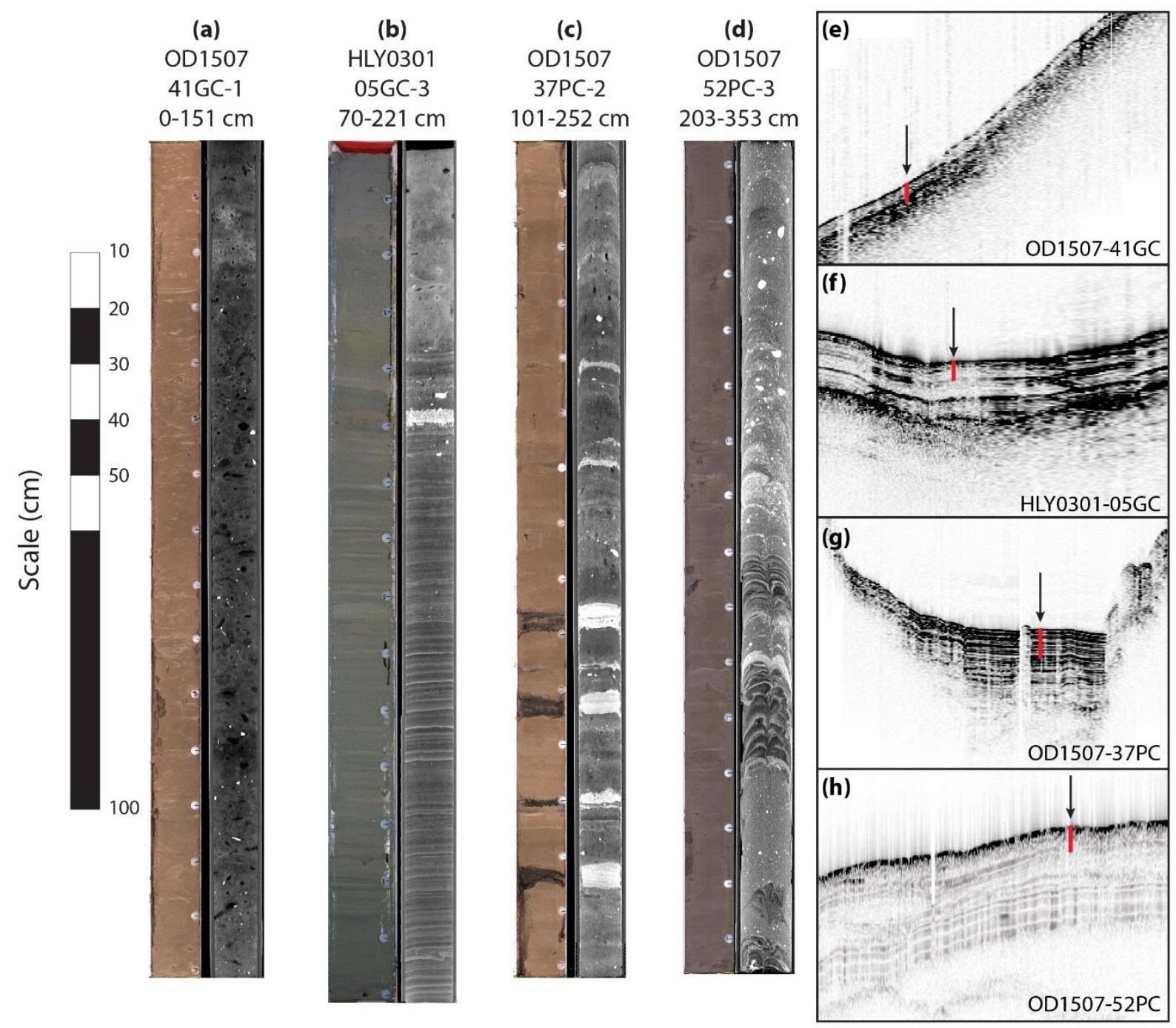

Supplementary Figure 1. Correlation of core lithofacies with seismo-acoustic facies III (a, b, e, f), IV (c, g) and V (d, h). Core 85 lithofacies are shown using CT scans and core photographs; seismo-acoustic facies at each core site are shown in panels e-h. The red bars in panels e-h represent the total core length for each core (using a velocity through sediment of $1500 \mathrm{~m} \mathrm{~s}^{-1}$ ); core locations are shown on Figure 2. 

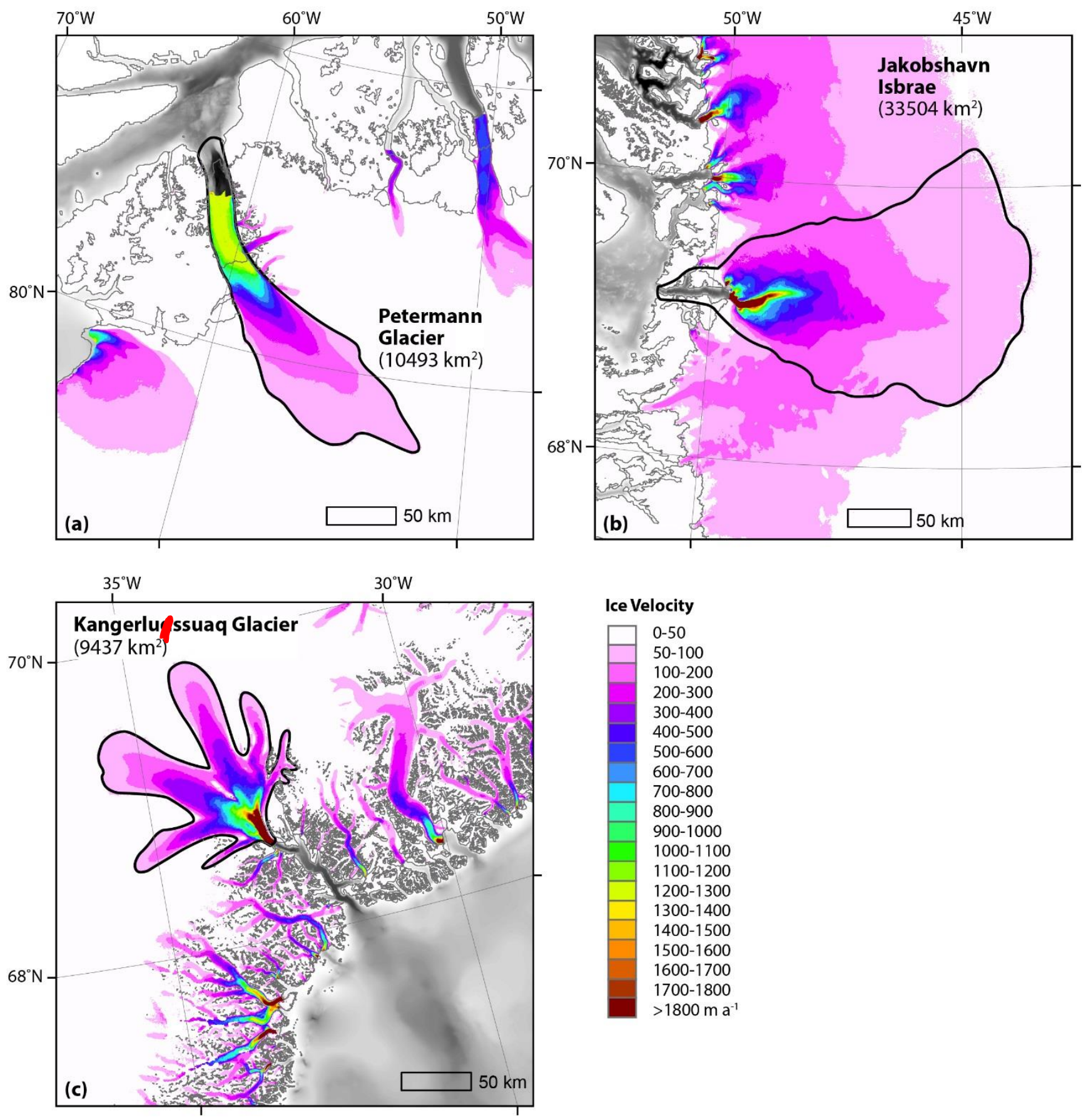

\section{Ice Velocity}

\begin{tabular}{|l|l|}
\hline & $0-50$ \\
$50-100$ \\
$100-200$ \\
$200-300$ \\
$300-400$ \\
$400-500$ \\
$500-600$ \\
$600-700$ \\
$700-800$ \\
$800-900$ \\
$900-1000$ \\
$1000-1100$ \\
$1100-1200$ \\
$1200-1300$ \\
$1300-1400$ \\
$1400-1500$ \\
$1500-1600$ \\
$1600-1700$ \\
$1700-1800$ \\
\hline$>1800 \mathrm{~m} \mathrm{a}^{-1}$
\end{tabular}

90 Supplementary Figure 2. Maps of Greenland outlet glaciers discussed in main text showing modern ice-sheet velocities (Howat, 2017) with drainage basins (black lines) and areas used in glacial erosion rate calculations for: (a) Petermann Glacier, Northwest Greenland; (b) Jakobshavn Isbrae, West Greenland; (c) Kangerdlugssuaq Glacier, East Greenland. 